\title{
Application of Artificial Neural Network to Improve Pleurotus sp. Cultivation Modelling
}

\author{
Abdul Sahli Fakharudin ${ }^{1}$, Norazwina Zainol ${ }^{2 *}$, and Noor Athirah Dzulkefli ${ }^{3}$ \\ ${ }^{1}$ Faculty of Computer Systems \& Software Engineering, Universiti Malaysia Pahang, 26300 Gambang, Pahang, Malaysia. \\ ${ }^{2}$ CARIFF, Universiti Malaysia Pahang, 26300 Gambang, Pahang, Malaysia \\ ${ }^{3}$ Faculty of Chemical \& Natural Resources Engineering, Universiti Malaysia Pahang, 26300 Gambang, Pahang, Malaysia.
}

\begin{abstract}
Mathematical modelling for nitrogen concentration in mycelium $(\mathrm{N})$ during Pleurotus sp. cultivation had successfully been produced using multiple linear regression. Two different substrates were used to cultivate the Pleurotus sp. which were empty palm fruit bunch (EFB) and sugarcane bagasse (SB). Both substrates were collected and prepared as the selected factors which were type of substrate (SB - A and EFB B), size of substrates $(0.5 \mathrm{~cm}$ and $2.5 \mathrm{~cm})$, mass ratio of spawn to substrate (SP/SS) $(1: 10$ and 1:14), temperature during spawn running $\left(25^{\circ} \mathrm{C}\right.$ and ambient) and pre-treatment of substrates (steam and non-steam). The response was nitrogen concentration in mycelium $(\mathrm{N})$. This paper presents the application of artificial neural network to improve the modelling process. Artificial neural network is one of the machine learning method which use the cultivation process information and extract the pattern from the data. Neural network ability to learn pattern by changing the connection weight had produced a trained network which represent the Pleurotus sp. cultivation process. Next this trained network was validated using error measurement to determine the modelling accuracy. The results show that the artificial neural network modelling produced better results with higher accuracy and lower error when compared to the mathematical modelling.
\end{abstract}

\section{Background}

Oyster mushroom or Pleurotus sp. cultivation has a good market potential in Malaysia but the fresh stocks of fresh mushrooms in the market are still inadequate to meet local demands [1]. Rubber sawdust is commonly used in Malaysia as a media for oyster mushroom cultivation. However, the low availability of rubber tree has become serious problem to the mushrooms grower. Thus, the new alternative substrates need to be used to overcome the shortage of mushroom production [2].

Modelling using artificial neural network (ANN) for fungal or mushroom growth had been studied by several researchers. [3] had used radial basis function ANN model and evaluated against the quadratic response surface method to predict the maximum growth of the ascomycetous fungus Monascus ruber. The ANN had lower RMSE of 0.063 compared to the polynomial modelling with RMSE of 0.156 . The modelling of xylanase production using fungal culture was done by [4] using four dependent variables had been studied. The modelling process used three ANN learning algorithms with the network architecture of 4-5-5-1. The results for the modelling RMSE between 2.2 to 7.7. The comparison of quadratic modelling with ANN modelling for Marasmius androsaceus submerged fermentation conditions by [5] also produced better result for the ANN modelling. The ANN model RMSE was 0.024 compared to the quadratic regression model with RMSE of 0.044. The ANN model used Levenberg-Marquardt training algorithm to search the suitable ANN weights to represent the process.

This paper presents the evaluation of factors affecting the mycelium growth in Pleurotus sp. cultivation by using agricultural waste. It also presents the application of ANN to improve the model of nitrogen concentration during the cultivation. The ANN model will be compared with the multiple linear regression model produced during the experiment.

\section{Materials And Methods}

\subsection{Collection of substrates and spawns}

The substrates which were empty palm fruit bunch (EFB) were collected from palm oil plantation, while coconut fiber (CF) were collected from coconut plantation and banana stem (BS) from banana farm at Banting, Selangor. While sugarcane bagasse (SB) was collected at Semenyih. Selangor, coffee ground (CG) and egg trays (ET) were obtained from home.

\subsection{Experimental set-up for factorial analysis}

There were five selected factors that give contribution to oyster mushroom growth (Table 1). The factors were type of substrates, size of substrates, mass ratio of spawn to substrates $(\mathrm{SP} / \mathrm{SS})$, temperature and pre-treatment of substrates. SB (A) and EFB (B) were prepared in bottles according to run in Table 2. Firstly, the substrates were cut into the selected size, then soaked in water for overnight, filtered to drain excess water and weighed for $100 \mathrm{~g}$. Then, the substrates were pre-treated with selected pre-treatment and inoculated with spawn by placing the spawn on the surface of substrate. The bottles were closed and incubated at selected temperature in the dark condition. The experiment set-up in Table 2 was performed by Design Expert software where all the factors were randomized [6]. Then, experimental data were analyzed by using Design Expert software in order

\footnotetext{
* Corresponding author: azwina@ump.edu.my
} 
to determine the most contributing factors. The experiment was conducted according to set-up in Table 2. The response variable in this study was nitrogen concentration in mycelium $(\mathrm{N})$.

Table 1. Selected factor and their range

\begin{tabular}{|c|c|c|c|}
\hline Factor & Factors & $\begin{array}{c}\text { Low } \\
\text { level }\end{array}$ & $\begin{array}{c}\text { High } \\
\text { level }\end{array}$ \\
\hline $\mathrm{A}$ & $\begin{array}{c}\text { Type of } \\
\text { substrate }\end{array}$ & $\mathrm{A}$ & $\mathrm{B}$ \\
\hline $\mathrm{B}$ & $\begin{array}{c}\text { Size of } \\
\text { substrates }\end{array}$ & $0.5 \mathrm{~cm}$ & $2.5 \mathrm{~cm}$ \\
\hline $\mathrm{C}$ & SP/SS & $1: 10$ & $1: 14$ \\
\hline $\mathrm{D}$ & $\begin{array}{c}\text { Temperature } \\
\text { during spawn } \\
\text { running }\end{array}$ & $25^{\circ} \mathrm{C}$ & Ambient \\
\hline $\mathrm{E}$ & $\begin{array}{c}\text { Pre-treatment } \\
\text { of substrates }\end{array}$ & Steam & $\begin{array}{c}\text { Non- } \\
\text { steam }\end{array}$ \\
\hline
\end{tabular}

Table 2. Experimental setup that has been constructed by using TLFA by Design Expert software (Version 7)

\begin{tabular}{|c|c|c|c|c|c|}
\hline & $\begin{array}{r}\text { Factor } \\
1\end{array}$ & $\begin{array}{r}\text { Factor } \\
2\end{array}$ & $\begin{array}{r}\text { Factor } \\
3 \\
\end{array}$ & Factor 4 & Factor 5 \\
\hline Run & A & B & $\mathrm{C}$ & D & $\mathrm{E}$ \\
\hline 1 & A & 0.5 & $1: 10$ & $25^{\circ} \mathrm{C}$ & Steam \\
\hline 2 & B & 0.5 & $1: 10$ & $25^{\circ} \mathrm{C}$ & $\begin{array}{r}\text { Non- } \\
\text { Steam }\end{array}$ \\
\hline 3 & A & 2.5 & $1: 10$ & $25^{\circ} \mathrm{C}$ & $\begin{array}{r}\text { Non- } \\
\text { Steam }\end{array}$ \\
\hline 4 & B & 2.5 & $1: 10$ & $25^{\circ} \mathrm{C}$ & Steam \\
\hline 5 & $\bar{A}$ & 0.5 & $1: 14$ & $25^{\circ} \mathrm{C}$ & $\begin{array}{r}\text { Non- } \\
\text { Steam }\end{array}$ \\
\hline 6 & B & 0.5 & $1: 14$ & $25^{\circ} \mathrm{C}$ & Steam \\
\hline 7 & $\mathrm{~A}$ & 2.5 & $1: 14$ & $25^{\circ} \mathrm{C}$ & Steam \\
\hline 8 & B & 2.5 & $1: 14$ & $25^{\circ} \mathrm{C}$ & $\begin{array}{r}\text { Non- } \\
\text { Steam }\end{array}$ \\
\hline 9 & A & 0.5 & $1: 10$ & Ambient & $\begin{array}{l}\text { Non- } \\
\text { Steam }\end{array}$ \\
\hline 10 & B & 0.5 & $1: 10$ & Ambient & Steam \\
\hline 11 & A & 2.5 & $1: 10$ & Ambient & Steam \\
\hline 12 & B & 2.5 & $1: 10$ & Ambient & $\begin{array}{r}\text { Non- } \\
\text { Steam }\end{array}$ \\
\hline 13 & A & 0.5 & $1: 14$ & Ambient & Steam \\
\hline 14 & B & 0.5 & $1: 14$ & Ambient & $\begin{array}{l}\text { Non- } \\
\text { Steam }\end{array}$ \\
\hline 15 & A & 2.5 & $1: 14$ & Ambient & $\begin{array}{r}\text { Non- } \\
\text { Steam }\end{array}$ \\
\hline 16 & B & 2.5 & $1: 14$ & Ambient & Steam \\
\hline
\end{tabular}

\subsection{Sample analysis}

Sample analysis was conducted after all run fully colonized with mycelium. The response variable was nitrogen concentration in mycelium $(\mathrm{N})$.

\subsection{Nitrogen concentration analysis by using HACH Spectrophotometer}

$\mathrm{N}$ was determined by using Persulfate Digestion Method (Method 10072). The mycelium was collected from the substrates and diluted by using deionized water using 40 dilution factor. Then, $\mathrm{N}$ was analyzed by using $\mathrm{HACH}$ Spectrophotometer.

\subsection{Data analysis}

All data obtained were recorded in Design Expert software. The responses were analyzed using ANOVA based on p-value with $95 \%$ of confidence level to identify the most contributing factors and interaction between the factors that has an effect on N[7].

\subsection{Artificial Neural Network Modelling}

The model had used basic architecture of 5 input node for all five factors and one output node for the nitrogen concertation $(\mathrm{N})$. Only the output node used linear activation function while the hidden node used sigmoid activation function. Two training algorithms[8] will be used to train the ANN model starting from the smallest number ( 2 hidden nodes) and will be increased until a significant ANN model can be generated thru the training process. The two training algorithms were backpropagation (BP) and Levenberg-Marquardt (LM) and the training process will be stopped when the training error reach 0.01 . The back-propagation learning rate and momentum were set to a small number of 0.1 because bigger value did not yield any significant ANN model during the preliminary run. The implementation of the ANN modelling had used the ENCOG 3.3.0[9] Java library with Netbeans 8.0.2 was used as the development IDE

The dataset was divided into 70:30 percent ratio with 11 random samples of the dataset was used as training and 5 samples was used as testing set. The dataset was normalized between 0 to 1 which followed the sigmoid activation function range. The network performance will be measured using mean square error (MSE) for comparison with the linear regression model.

\section{Results And Discussion}

\subsection{Factorial analysis}

Table 4 shows 16 runs of experiments were done for this study and the results of nitrogen concentration (N). The multiple linear regression model was utilized to express the $\mathrm{N}$ concentration as a function of independent factors as shown in Eq. (1):

$\mathrm{N}$ concentration $=352+241.5 \mathrm{~A}+43 \mathrm{~B}-0.5 \mathrm{C}+50.5 \mathrm{D}+$ $21.5 \mathrm{E}+59.5 \mathrm{AB}+41 \mathrm{AD}-35.5 \mathrm{BC}+47.5 \mathrm{BE}-33 \mathrm{CD}-$ $39 \mathrm{CE}+32 \mathrm{DE}(1)$

where the and A, B, C, D, E are the coded values of type of substrate, size of substrate, SP/SS, temperature and pre-treatment of substrate, respectively. The term of $A$, $\mathrm{B}, \mathrm{C}, \mathrm{D}$ and $\mathrm{E}$ are denoted as the main effects, while $\mathrm{AB}$, $\mathrm{AD}, \mathrm{BC}, \mathrm{BE}, \mathrm{CD}, \mathrm{CE}$ and $\mathrm{DE}$ are the interaction involves in the process. Table 5 shows the comparison between the experimental value (actual) and predicted value from equation (1) for $\mathrm{N}$ concentration. 
The response was analyzed using ANOVA by using Design Expert software based on the value with $95 \%$ confidence level to identify the most contributing factors and interaction between the factors on $\mathrm{N}$ concentration. $\mathrm{N}$ was ranged from 76 to $1040 \mathrm{mg} / \mathrm{L}$. The lowest value of $76 \mathrm{mg} / \mathrm{L}$ of $\mathrm{N}$ was obtained at substrate $\mathrm{A}, 2.5 \mathrm{~cm}$ size of substrate, 1:14 SP/SS, incubated at ambient temperature no application of steam treatment; the highest value of $1040 \mathrm{mg} / \mathrm{L}$ of $\mathrm{N}$ was obtained at substrate $\mathrm{B}, 2.5 \mathrm{~cm}$ size of substrate, $1: 10 \mathrm{SP} / \mathrm{SS}, 25^{\circ} \mathrm{C}$ and application of steam treatment.

Table 4. Experimental results of nitrogen concentration (N)

\begin{tabular}{|c|c|c|c|c|c|c|}
\hline Run & $\begin{array}{l}\text { Fact } \\
\text { or } 1\end{array}$ & $\begin{array}{c}\text { Factor } \\
2\end{array}$ & $\begin{array}{c}\text { Factor } \\
3\end{array}$ & Factor 4 & Factor 5 & $\begin{array}{c}\text { Resp } \\
\text { onse } \\
\mathrm{N} \\
(\mathrm{mg} / \\
\mathrm{L})\end{array}$ \\
\hline 1 & A & 0.5 & $1: 10$ & $25^{\circ} \mathrm{C}$ & Steam & 136 \\
\hline 2 & B & 0.5 & $1: 10$ & $25^{\circ} \mathrm{C}$ & $\begin{array}{l}\text { Non- } \\
\text { Steam }\end{array}$ & 476 \\
\hline 3 & A & 2.5 & $1: 10$ & $25^{\circ} \mathrm{C}$ & $\begin{array}{l}\text { Non- } \\
\text { Steam }\end{array}$ & 92 \\
\hline 4 & $\mathrm{~B}$ & 2.5 & $1: 10$ & $25^{\circ} \mathrm{C}$ & Steam & 1040 \\
\hline 5 & A & 0.5 & $1: 14$ & $25^{\circ} \mathrm{C}$ & $\begin{array}{l}\text { Non- } \\
\text { Steam }\end{array}$ & 164 \\
\hline 6 & $\mathrm{~B}$ & 0.5 & $1: 14$ & $25^{\circ} \mathrm{C}$ & Steam & 560 \\
\hline 7 & $\mathrm{~A}$ & 2.5 & $1: 14$ & $25^{\circ} \mathrm{C}$ & Steam & 88 \\
\hline 8 & B & 2.5 & $1: 14$ & $25^{\circ} \mathrm{C}$ & $\begin{array}{l}\text { Non- } \\
\text { Steam }\end{array}$ & 664 \\
\hline 9 & A & 0.5 & $1: 10$ & Ambient & $\begin{array}{l}\text { Non- } \\
\text { Steam }\end{array}$ & 128 \\
\hline 10 & $\mathrm{~B}$ & 0.5 & $1: 10$ & Ambient & Steam & 356 \\
\hline 11 & A & 2.5 & $1: 10$ & Ambient & Steam & 120 \\
\hline 12 & B & 2.5 & $1: 10$ & Ambient & $\begin{array}{c}\text { Non- } \\
\text { Steam }\end{array}$ & 472 \\
\hline 13 & A & 0.5 & $1: 14$ & Ambient & Steam & 80 \\
\hline 14 & B & 0.5 & $1: 14$ & Ambient & $\begin{array}{c}\text { Non- } \\
\text { Steam }\end{array}$ & 572 \\
\hline 15 & A & 2.5 & $1: 14$ & Ambient & $\begin{array}{c}\text { Non- } \\
\text { Steam }\end{array}$ & 76 \\
\hline 16 & B & 2.5 & $1: 14$ & Ambient & Steam & 608 \\
\hline
\end{tabular}

Table 5. Comparison between Actual Value from experiment and Predicted Value

\begin{tabular}{|r|r|r|r|}
\hline $\begin{array}{r}\text { Standard } \\
\text { Order }\end{array}$ & \multicolumn{2}{|l|}{$\begin{array}{l}\text { Actual } \\
\text { Value }\end{array}$} & \multicolumn{2}{l|}{$\begin{array}{l}\text { Predicted } \\
\text { Value }\end{array}$} & \multicolumn{1}{l|}{ Residual } \\
\hline 1 & 128 & 68.5 & 59.5 \\
\hline 2 & 356 & 312.5 & 43.5 \\
\hline 3 & 120 & 163.5 & -43.5 \\
\hline 4 & 472 & 531.5 & -59.5 \\
\hline 5 & 80 & 88.5 & -8.5 \\
\hline 6 & 572 & 564.5 & 7.5 \\
\hline 7 & 76 & 83.5 & -7.5 \\
\hline 8 & 608 & 599.5 & 8.5 \\
\hline 9 & 136 & 179.5 & -43.5 \\
\hline 10 & 476 & 535.5 & -59.5 \\
\hline 11 & 92 & 32.5 & 59.5 \\
\hline
\end{tabular}

\begin{tabular}{|r|r|r|r|}
\hline 12 & 1040 & 996.5 & 43.5 \\
\hline 13 & 164 & 171.5 & -7.5 \\
\hline 14 & 560 & 551.5 & 8.5 \\
\hline 15 & 88 & 96.5 & -8.5 \\
\hline 16 & 664 & 656.5 & 7.5 \\
\hline
\end{tabular}

\subsection{Analysis of variance (ANOVA) for nitrogen concentration in mycelium $(\mathrm{N})$}

Table 6 shows the percentage contribution for each factor towards nitrogen concentration in mycelium $(\mathrm{N})$ which is type of substrate (A) has the highest percentage with value of $75.80 \%$, followed temperature (D), size of substrate (B), pre-treatment of substrate (E) and lastly $\mathrm{SP} / \mathrm{SS}$ has the least percentage with value $0.0003 \%$. ANOVA summary was shown in Table 7. This model showed $\mathrm{R}^{2}$ was 0.9819 . Since the $\mathrm{R}^{2}$ for this response variables are higher than 0.8 , this model was accepted. It can be concluded that this model can be used for optimization.

Table 6. Contribution factors of nitrogen concentration in mycelium $(\mathrm{N})$

\begin{tabular}{|c|c|}
\hline Factor & \% Contribution \\
\hline A - Type of substrate & 75.80 \\
\hline B - Size of substrate & 2.40 \\
\hline C - SP/SS & 0.0003249 \\
\hline D - Temperature & 3.31 \\
\hline E - Pre treatment of substrate & 0.60 \\
\hline
\end{tabular}

Table 7. ANOVA for nitrogen concentration in mycelium (N)

\begin{tabular}{|c|c|c|c|c|c|}
\hline Source & $\begin{array}{c}\text { Sum of } \\
\text { square }\end{array}$ & Df & $\begin{array}{c}\text { Mean } \\
\text { Square }\end{array}$ & F value & $\begin{array}{c}\text { P- } \\
\text { value } \\
\text { Prob }> \\
\text { F }\end{array}$ \\
\hline Model & $\mathbf{1 . 2 0 9 E}+\mathbf{0 6}$ & $\mathbf{1 2}$ & $\mathbf{1 . 0 0 7 E}+\mathbf{0 5}$ & $\mathbf{1 3 . 5 9}$ & $\mathbf{0 . 0 2 7 0}$ \\
\hline A & $9.332 \mathrm{E}+05$ & 1 & $9.332 \mathrm{E}+05$ & 125.85 & 0.0015 \\
\hline B & 29584.00 & 1 & 29584.00 & 3.99 & 0.1397 \\
\hline C & 4.00 & 1 & 4.00 & $2.395 \mathrm{E}-$ & 0.9829 \\
& & & & 04 & \\
\hline D & 40804.00 & 1 & 40804.00 & 5.50 & 0.1007 \\
\hline E & 7396.00 & 1 & 7396.00 & 1.00 & 0.3915 \\
\hline AB & 56644.00 & 1 & 56644.00 & 7.64 & 0.0699 \\
\hline AD & 26896.00 & 1 & 26896.00 & 3.63 & 0.1529 \\
\hline BC & 20164.00 & 1 & 20164.00 & 2.72 & 0.1977 \\
\hline BE & 36100.00 & 1 & 36100.00 & 4.87 & 0.1145 \\
\hline CD & 17424.00 & 1 & 17424.00 & 2.35 & 0.2228 \\
\hline CE & 24336.00 & 1 & 24336.00 & 3.28 & 0.1677 \\
\hline DE & 16384.00 & 1 & 16384.00 & 2.21 & 0.2339 \\
\hline
\end{tabular}

\subsection{Artificial Neural Network Model}

The ANN model using BP training algorithm only produced a good and significant result when the hidden node was set to 10 hidden nodes. Under 10 hidden nodes the training was in endless loop because it was not be able to find the network error below 0.01 . The training was done in ten runs with the lowest error was produced by run number one with training MSE of 0.0093 and testing MSE of 0.0468. From Figure 1, model produced 
by the BP algorithm had very similar MSE which shows a similar convergence to the given training set. On the testing its also shows similar MSE except for run number eight which had a very high MSE around 3.2 as shown in Figure 2. This model unable to predict unknown data and predict a very different result than the other models. The LM algorithm produced better result with the best error with 7.874E-06 training MSE and 0.0610 testing RMSE for the model produced by run number one as shown in Figure 3 and 4. It also produced much lower number hidden node with 5-4-1 network structure. Both training and testing MSE for all runs have similar values and its shows that the LM algorithm produced model with better accuracy and better in predicting unknown inputs.

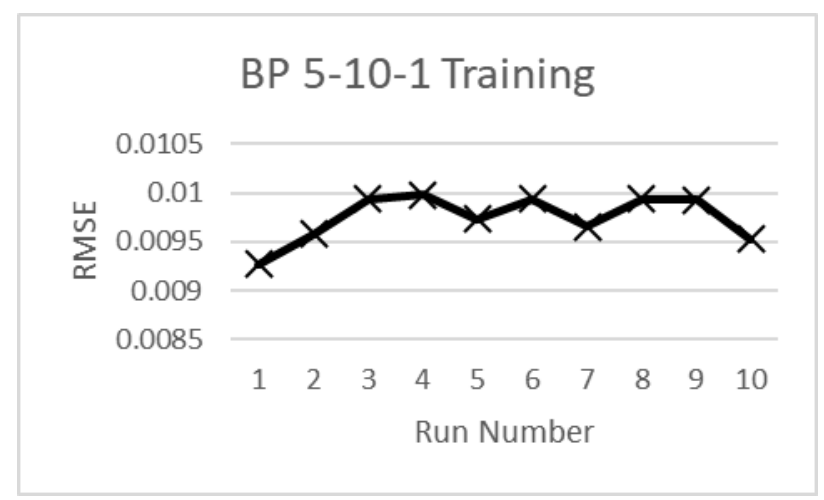

Fig. 1. Back-propagation training results

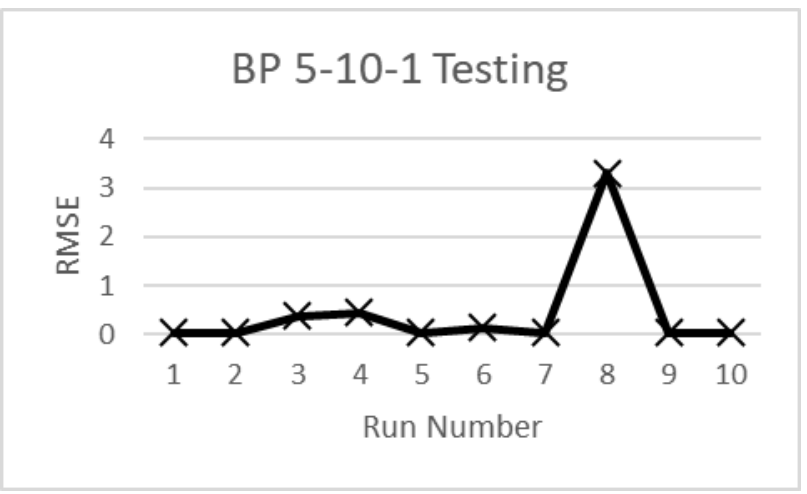

Fig. 2. Back-propagation testing results

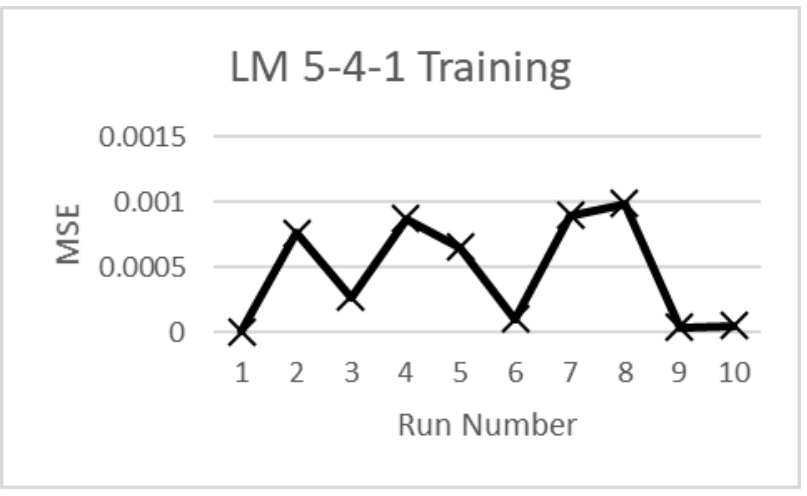

Fig. 3. Levenberg-Marquardt training results

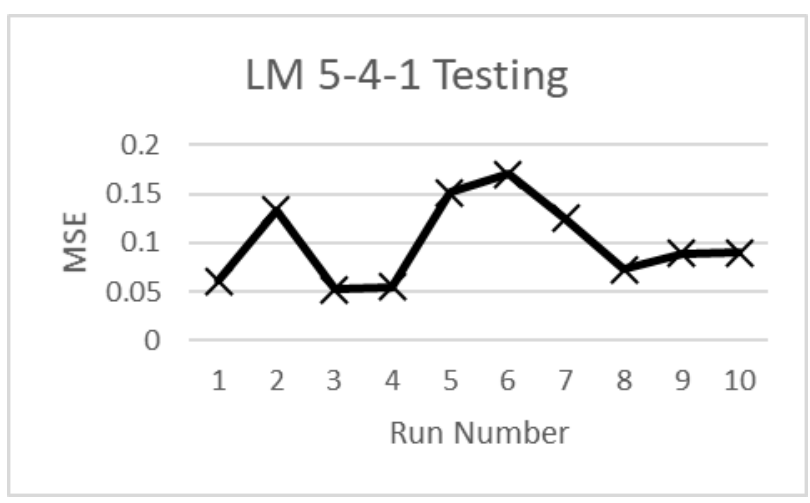

Fig. 4. Levenberg-Marquardt testing results

For modelling comparison, the MSE calculation was done to the denormalized output of the network for direct comparison with the multiple linear regression. The process required another set of MSE calculation, but it was done only to the best ANN model which was the model run number one for each training algorithms. Table 8 shows the comparison of the regression modelling with the ANN modelling. From the ANOVA analysis, the multiple linear regression produced $1.007 \mathrm{E}+05 \mathrm{MSE}$ and it was for all 16 samples. The ANN model had training and testing samples where it had its own MSE and overall MSE was calculated by adding both training and testing MSE. The results in Table 8 shows that the ANN using BP algorithm did not improve the linear regression model. All the training, testing and overall MSE were higher than the regression model. As mentioned before the model from the BP did not converge very well compared to the ANN model using LM algorithm. The LM algorithm produced a lower MSE for both linear regression and BP algorithm with overall MSE of $2.421 \mathrm{E}+04$.

Table 8: Modelling Comparison

\begin{tabular}{lc}
\hline Model & MSE \\
\hline Linear Regression & $1.007 \mathrm{E}+05$ \\
ANN BP training & $1.699 \mathrm{E}+05$ \\
ANN BP testing & $2.174 \mathrm{E}+05$ \\
ANN BP overall & $3.873 \mathrm{E}+05$ \\
ANN LM training & $8.637 \mathrm{E}+03$ \\
ANN LM testing & $5.673 \mathrm{E}+04$ \\
ANN LM overall & $2.421 \mathrm{E}+04$ \\
\hline
\end{tabular}

\section{Conclusions}

The purpose of this study is to evaluate the factors affecting the mycelium growth in Pleurotus sp. cultivation by using agricultural waste. The results showed that the type of substrate was the significant factor for nitrogen concentration (N). The best 
conditions for the mycelium growth of Pleurotus sp. cultivation were using substrate B (EFB), $2.5 \mathrm{~cm}$ size of substrate, 1:14 mass ratio, incubated at ambient temperature and application of steam treatment to substrate with $656 \mathrm{mg} / \mathrm{L}$ of $\mathrm{N}$.

Model performance comparison had shown that the ANN model with LM algorithm had improved the modelling performance with low MSE when compared with the multiple linear regression model.

\section{Acknowledgement}

The authors wish to acknowledge the Universiti Malaysia Pahang for funding the project under grant RDU1803119 and RDU170393.

\section{References}

1. A. Chan, (2017) [Online] https://www.pressreader.com/malaysia/the-starmalaysia/20170221/281621010100603

2. H. T. Hoa, C.-L. Wang, and C.-H. Wang, Mycobiology 43:4, 423-434 (2015)

3. E. Z. Panagou, V. Kodogiannis, and G. J.-E. Nychas, Int. J. Food Microbiol. 117:3, 276-286 (2007)

4. M. Meshram, A. Kulkarni, V. K. Jayaraman, B. D. Kulkarni, and S. S. Lele, Biochem. Eng. J. 40:2, 348-356 (2008)

5. F. Meng, G. Xing, Y. Li, J. Song, Y. Wang, Q. Meng, J. Lu, Y. Zhou b, Y. Liu, D. Wang, L. Teng, Saudi J. Biol. Sci. 23(1), S99-S105 (2016)

6. K. A. Samad and N. Zainol, Ind. Crops Prod. 95, 202-206 (2017)

7. N. Zainol, N. Thangaperumal, N. H. Zahari, and N. H. Aziz, MATEC Web Conf. 78, (2016)

8. A. S. Fakharudin, M. N. Sulaiman, and N. Mustapha, Adv. Sci. Lett. 24:10, 7582-7587 (2018)

9. J. Heaton, (2018) [Online] https:/github.com/encog/encog-java-core 